\title{
Poor Organ Donation in Vietnam: Resulting from Beliefs, Religions, and Traditional Culture? How to Promote Organ Donation and to Deal with Organ Trading from a Legal Perspective?
}

\author{
Le Lan Chi
}

\section{Department of Criminal Justice, School of Law, Vietnam National University, Hanoi, Vietnam}

\begin{abstract}
In Vietnam, organs are always in great demand while the organ supply from brain dead donors is extremely small, prompting the search for organs supplied by living people. People in need of an organ transplant either have to wait for a legally supplied organ (coming from any voluntary and non-commercial donation) or resort to an illegal supplied one (through organ trading). Therefore, increasing the number of legally supplied organs and controlling illegal source of supply are problems to be solved by Vietnam. This paper discovers whether religions, beliefs, traditional culture, and current legislation impede the organ donation or not. In addition, this paper also aims to find out legal loopholes resulting in ineffective handling of organ trading, then proposing solutions to improve the law to promote the legal supply of organs and effectively combat crimes related to organs illegally supplied by organ trading.
\end{abstract}

Keywords: Organ donation, organ trading, belief and religion, traditional culture, law, Vietnam.

\section{INTRODUCTION}

Vietnam has been facing the biggest difficulty in organ transplant, which was organ shortage. According to data provided by the National Monitoring Center of Organ Transplant of Vietnam (2021), the number of registered donors (who voluntarily donate organs upon their brain death) is small, with 19,454 people. There have been merely 110 cases of organ donation by the brain-dead. Meanwhile, the number of organ transplant registrants in the national transplant wait list is 2,428 , not to mention those who are not in the list. Of the transplanted organs, the main source came from living donors, accounting for more than $93.7 \%$. The supply of organs donated by brain-dead people was poor, with only $6.3 \%$. There were about ten brain-dead patients per year who were encouraged and agreed to donate organs. In 2019 , only 20 cases of such donation were recorded, which was the highest number. This led to an undersupply and contributes to the establishment of "black" markets for organ trade and the commitment of crimes with the purpose of appropriating and trading organs.

To answer the question as to how the law should promote an increase in the legal supply of organs, including those voluntarily donated by the brain dead and living people, it is necessary to determine the appropriate approach of the law to beliefs, religions, and traditional culture. Previous studies have proven that beliefs, religions, and traditional culture are impediments to a voluntary organ donation. The

*Address correspondence to this author at the Department of Criminal Justice, School of Law, Vietnam National University, Hanoi, Vietnam;

E-mail: lelanchi@vnu.edu.vn influence of beliefs, religions, and traditional culture on voluntary organ donation has been more or less studied in Asia (Concejero and Chen 2009; Tai 2009), in the Southeast Asia region as well as in Vietnam. Studies showed that in Asia as well as in Southeast Asia, religions and traditional culture had a great influence on the lives of individuals (Chen, Kabiling, and Concejero 2013). Chen et al. (2013) also mentioned that the standards of conduct influenced by religions and culture became an obstacle to the organ donation decision-making process. However, to be more specific, in Vietnam, most of the studies merely focused on giving explanations from the perspective of religion, with the two major religions being Buddhism and Christianity, by surveying the opinions of religious dignitaries (Duong Hai 2018) and explanations based on burial practices in traditional culture (Duong Hai 2018; Hai Van 2018; Pham 2015). Previous studies failed to give deep insights into the role of indigenous belief, other conceptions and ideas stemming from the traditional culture in the interaction with new living standards of contemporary society. In an attempt to overcome the limitations of previous studies, this paper will provide an analysis of indigenous beliefs and traditional culture, thus, giving suggestions to law makers as to whether it is necessary to take beliefs, religions, and traditional culture into account or stand up boldly for changes. The method adopted in this section is document synthesis method and alignment evaluation method. The former is used to collect previous in-depth studies on the characteristics and role of beliefs, religions, and traditional culture in Vietnam. The latter is used to show whether organ donation is in alignment with the values and behavioral standards set by beliefs, religions, and traditional culture in Vietnam. 
Vietnam has not been able to eliminate organ trade activities on the "black market" operating under the rule of supply and demand and for commercial purposes. To solve this problem, other than the increase in voluntary organ donations (especially by registered donors after their brain death), the second question is how will the law be improved to prevent crimes relating to organ trading? Studies in Vietnam on the role of law in handling organ trading in the country were extremely limited. This paper will point out legal loopholes, especially those in the criminal law, in order to propose solution to the improvement of the current legal system. Expert method is used to collect opinions of those directly coordinating and managing organ transplant on limitations of the law they find out in their practice. Doctrinal method (black letter method) is used to show the incompatibility of current legal regulations. These two methods are applied to identify drawbacks of the current law in the combat with crimes relating to organ trading.

\section{THE RELATIONSHIP BETWEEN BELIEFS, RELIGIONS, TRADITIONAL CULTURE OF VIETNAMESE PEOPLE AND ORGAN DONATION AND THE ROLE OF LAW IN PROMOTING ORGAN DONATION}

\section{The Relationship between Beliefs, Religions, Traditional Culture of Vietnamese People and Organ Donation}

Religious belief, society, and organ donation are interrelated in most Asian countries. A close connection between organ donation and transplantation and people's outlook on life, established by the former's existential character, has an effect on their relevant decisions (Röcklinsberg 2009). One of the issues that call for resolution by ethicists in organ transplantation is to understand religious beliefs in Asia (Concejero and Chen 2009). In Vietnam, the influence of religious concepts has its own nuances. Vietnam has two main indigenous beliefs, namely Ancestor worship and Mother Goddess one. Those two indigenous folk beliefs, despite having not been recognized as religion yet, hold a special position in the spiritual life that cannot be replaced by religion.

\section{Indigenous Beliefs}

\section{Ancestor Worship Belief}

Ancestor worship is a belief, ethic and spiritual support to fulfil the psychological needs of Vietnamese people and all religions introduced into Vietnam must accept this belief sooner or later (Nguyen 2007:16).
According to this belief, death is a return to ancestors and the ancestors may follow and bless their descendants. This is also the foundation of ancestor worship. Ancestor worship belief indirectly lays the responsibility for ensuring a fulfilling physical, material and spiritual life of grandparents and parents (who have died) on the descendants (the living). The integrity of the body is, therefore, of great importance, because it is the basis for a fully functioning body in a long, or even permanent afterlife. The well-being and the integrity of the body of each person is the condition and the means to produce offspring and maintain the presence of the previous generation in the present and in the future. Vietnamese people also highly value their bodily integrity and the responsibility to preserve this integrity because their bodies are the products of their parents. Therefore, children are responsible for preserving the body given by their parents. This moral obligation is not only influenced by ancestor worship but also the adoption and reformulation of the Confucian concept of filial piety introduced into Vietnam thousands of years ago. According to Confucianism, everyone is born with a complete body, so the dead body should also be kept intact to show filial respect to our parents' gifts, which involve body, hair and skin. Therefore, as indicated by this philosophy, organ donation basically fails to show a son or daughter's devotion and respect to parents (Tai 2009:91).

Ancestor worship belief also goes hand in hand and is coupled with Yin House Feng Shui - a component of feng shui about the location of graves for ancestors, grandparents, and parents. Vietnamese people mainly follow burial practices according to which the entire dead body is buried for the first time and several years later, the remains will be 'reinterred' as a permanent burial ritual. In this reinternment process, no bone is missing, and the integrity of the bones must be ensured (Pham 2011:193-194). As mentioned above, Vietnamese people's concept of the integrity of the body and the corpse comes from the respect for ancestors in Ancestor worship belief and is consistent with the Confucian concept of filial piety. Toan Anh (1992:348) also stated that the integrity of the body and corpse was also influenced by Yin House Feng Shui to seek benefits for descendants. Maintaining the integrity of the body and corpse of deceased loved ones is pragmatic because it will directly bring well-being and success to the current life. Therefore, ancestor worship belief, which mainly aims at the preparation by human beings for life after death, plays a unique and important role in traditional culture and major religions introduced into Vietnam. 


\section{Mother Goddess Worship Belief}

Mother Goddess worship belief is an indigenous belief, reflecting the Mother Goddess principle in Vietnamese traditional culture. In Vietnamese folk life, Mother Goddess ( $M a ̂ ̃ u$ ) is omnipresent, and at the same time Mother Goddess has also become a philosophy about the world and people. It seems that Vietnamese people believe in the complementarity between Buddha and Mother Goddess. Buddha saves mankind and protects the world while Mother Goddess renders assistance in specific and practical things (Nguyen 2012:154). Like ancestor worship, the Mother Goddess worship belief manifests a very practical spiritual need of the Vietnamese, which is regarded as "A Bit of a Spirit Favor is Equal to a Load of Mundane Gifts" (Một miếng lộc thánh bằng một gánh lộc trần) (Vietnamese idiom). Rather than mainly aiming at people and their belief about the afterlife, Mother Goddess focuses on the current world where people need health, wealth and career. This is a positive outlook on life, suitable to the concept of "existentialism" of people in the modern world". Therefore, like ancestor worship, Mother Goddess worship also reveals the 'practicality' and 'pragmatism' of Vietnamese indigenous beliefs.

Major Religions in Vietnam and their Connection with Indigenous Beliefs

At the time those religions were born, science was far from developed, so organ donation and transplantation had not been thought of yet. It was not until the recent decades that organ donation and transplantation began to emerge. However, it is a traditional belief of all religions in the world that saving someone's life is the most important, even if organ donation also gains the approval of major religions, despite any possible opposition (Bruzzone 2008).

As organ donation and transplantation are new issues, they have not been mentioned in any religious tenets or indigenous beliefs in Vietnam. On the other hand, most of the population are not followers of any religion. Vietnam is a multi-religious country with over 24 million followers (accounting for about $27 \%$ of the population, of which more than 11 million are Buddhists, 8 million are Catholics and Protestants, about 80,000 are Muslims, and the rest are followers of other religions (National ASEAN 2020 Committee 2020). If religion is perceived according to the approach applied in this paper, the remarks of Tran (2002:15) about Vietnamese people's having no interest in any religion are relatively correct.
Meanwhile, indigenous beliefs play a vital role, covering aspects that are not dealt with by religions because indigenous beliefs offer solutions to mundane issues faced by human beings. The assessment hereinafter seems to contradict that of Tran (2002) mentioned above, but actually, they are consistent with each other. "The Annamites have a strong religious spirit. I mean religion is associated with every action of their own life and they silently believe in the existence and control of supernatural beings over them, and that their happiness depends on how supernatural beings interfere with the affairs of this mundane world" (Cadiere 1997:38). It seems that his definition of religion was based on the theory of Durkheim; therefore, his expression, "The Annamites have a strong religious spirit", is very subtle. On the other hand, Cadiere (1997) also pointed out the pragmatism of the Vietnamese belief practice and the core that created the existential value of Vietnamese indigenous beliefs. A typical example is Buddhism which came to Vietnam very early, in the second and third centuries AD. However, some modifications to Buddhism were required when it came to Vietnam in order to adapt and integrate with other spiritual philosophies, and the Buddhist notion of letting go of the body after death had a limited impact on Vietnamese people's life compared to ancestor worship belief and Yin house Feng shui factor. Many Vietnamese people going to the pagoda to worship Buddha do not intend to pray for being liberated or entering Nirvana, returning to the Buddha realm, but to pray for talent, wealth, health and peace for themselves and their loved ones, which are matters of the mundane world (Nguyen 2020:76).

Thus, religion is not a bottleneck of voluntary organ donation in Vietnam. Indigenous beliefs do not directly come into conflict with organ donation (because organ donation is an emerging issue) but the pragmatism in the practice of beliefs and the existentialism of Vietnamese indigenous beliefs have indirectly created barriers to the willingness to donate organs of each individual.

\section{Traditional Culture}

\section{Yin and Yang Philosophy}

Located in the Southeast Asia, where the foundation of the Yin and Yang philosophy was formed, Vietnam is the only Southeastern country to adopt this philosophy after it was fully developed by China (Tran 2016:204). According to Yin and Yang philosophy, the human body is a miniature version of the universe. Each organ system is related to each of the five 
elements, the correlation among which are interpromoting, interacting, overriding and counteracting, according to a strict logic on the basis of Yin and Yang balance and harmony. Therefore, diseases are explained by the imbalance of Yin and Yang. In other words, the balance between Yin and Yang is the underlying factor of the living and human's health. Yin and Yang become the instrument to consider all clinical diagnose of a person's health (Tran 2016:204). The balance of Yin and Yang serves as the basis of life, as well as the foundation of human health, by classifying the body parts, organs, and blood into different Yin and Yang aspects and elements of the five elements. The lack of any part of the human body leads to a structural disruption and changes in the whole system. Therefore, this philosophy is one of the barriers to organ donation in the modern times. This is because organ donation is not only about the removal of a part of the human body but also the disruption to the bodily integrity and consistency of different functions of the body.

\section{Sentimentalism}

Sentimentalism or the promotion of sentimental behaviors is an important feature in Vietnamese culture, which focuses on the emotional and moral aspects over the doctrinal and philosophical ones (Nhu Tho 2012). "Respecting other's feelings and being sentimental", without any doubt, are values of Vietnamese traditional culture. It is one of the typical products of the emphasis on Yin which is a characteristic of a typical culture that emphasizes Yin factor in the Southeast Asian wet rice cultivation region (Tran 2016: 377). Vietnamese people also uphold the spirit of solidarity through "Loving other people as much as loving yourself" (Thương người như thể thương thân), or "If a horse hurts, the entire stable stops eating"' (Một con ngựa đau cả tàu bỏ cỏ) (Vietnamese proverbs), and etc. In folklore, Vietnamese people attach great importance to filial piety towards parents, and one of the typical models for filial piety and sacrifice is the popular folk tale in Vietnamese culture "Thoai Khanh - Chau Tuan". Thoai Khanh cut her flesh for her mother-in-law (Chau Tuan's mother) to relieve her hunger, and offered her eyes in exchange for her mother-in-law's life. Organ donation can also become a cultural value of the modern society because first of all, it is consistent with sentimentalism and the virtue of humanity in Vietnamese culture.

In conclusion, in Vietnam, it is traditional culture and especially the belief in the causal relationship between the integrity of the dead body and afterlife and the life of the living that directly set up barriers to organ donation. Vietnamese traditional culture includes conflict between characteristics and conceptions and the existence of values and non-values. For example, although people may be selfish and narrow-minded, they are willing to give up personal plans and sacrifice their own rights and interests for the common good in hard times, wartime, or during natural disaster periods. Thus, the law is required to take suitable approaches, which are on the one hand, to refrain from setting out regulations against beliefs and traditional culture, such as regulations on compulsory organ donation; on the other hand, to bring in regulations on honoring and supporting willing donors of organ and their families in order to encourage voluntary donation which is the result of the altruism and sentimentalism in Vietnamese traditional culture and the support from religious institutions. Thus, vague and old-fashioned concepts of indigenous beliefs will be limited, and the sacred values and principle of voluntariness in organ donation will be protected by the introduction and improvement of regulations on criminalizing acts against voluntary donation, which are organ trading and appropriation.

\section{The Legal Approach of Vietnam to Organ Donation and Weaknesses of the Law in Promoting Organ Donation}

In religions and cultures, death is attached to multiple cultural and social significance, which requires the respect from organ donation system (Huang et al. 2015:144). Today, when traditional culture's and beliefs' conception about the integrity of both the dead body and live ones remains a burden, Vietnam's approach is "based on voluntarism and altruism" (Tran et al. 1999). This aforesaid approach neither stems from imposition nor compulsion and does not conflict with beliefs, religions and traditional culture. To be more specific, the current solution of Vietnam's law is to both respect the will of voluntary organ donors and create a source of tissues, organs and cadavers donated by the deceased who have not expressed their consent to donation when they are alive. Specifically, according to the Law on donation, removal and transplantation of human tissues and organs and the donation and recovery of cadavers 2006, the removal of tissues and organs from deceased donors may be carried out firstly by their consent expressed before their death (having a registration card for donation of deceased donors' tissues or organs) (Article 21, clause 2 , point $a$ and b); or, secondly, by written consent of the father, mother, guardian, spouse or adult child of the deceased donors (Article 21, clause 2, point c) upon 
their death in case they do not express their consent to donation after death (having no registration card for donation of deceased donors' tissues or organs). Besides, the law of Vietnam has set out regulations on promoting organ donation in two ways, namely honoring and supporting the donors and their families.

\section{Regulations in Honour of Organ Donors}

The recognition granted by the community, which is a great asset in Asia, to organ donors can be a form of non-financial assistance to them (Chan-On et al. and Sarwal 2017). However, to obtain community recognition, donors should be firstly entitled to adequate appreciation and honor from the government. The regulations on honoring organ donors need to be paid attention to because this is the way to use the law to shape new moral values of the modern society and step by step eliminate conservative notions of beliefs and traditional cultures. In Vietnam, regulations in honour of organ donors have also been introduced but are not really satisfactory. More precisely, in Vietnam, there is only Macchabee ceremony held within the medical profession to pay tribute to those who have dedicated their bodies to science (honoring those who donated their bodies for medical studies and teaching) and no regulation has been brought in to express deep gratitude to organ donors. As provided in the Law on donation, removal and transplantation of human tissues and organs and the donation and recovery of cadavers 2006, those who already donated organs are awarded a "medal" (Article 17). However, the law fails to set out any regulations in honour of the families of organ donors in the form of a medal or any others when they agree to donate the organs of their deceased loved ones.

\section{Regulations on Supports for Organ Donors and their Close Relatives}

Currently, the law of Vietnam basically only sets out regulations on support for living organ donors. According to the Law on donation, removal and transplantation of human tissues and organs and the donation and recovery of cadavers 2006, besides the aforesaid recognition, organ donors are entitled to free health care and rehabilitation right after their donations are conducted at medical institutions, free regular health checks, free health insurance cards, and prioritized transplantation of human tissues or organs at the prescription of a medical institution (Article 17). Regarding deceased organ donors, they are entitled to funeral and burial regime for deceased donors in accordance with Circular no. 104/2017/TT- BTC of the
Ministry of Finance dated 5 October 2017 on the management and use of funds for services for those who have donated organs and cadavers (Article 3). Nevertheless, there has been no regulation on support for their families, especially families deciding to donate the organs of their brain-dead loved ones who have not registered for donation before their brain death, or in other words, they are forgotten in Vietnam legislation.

Support currently granted by Vietnam to organ donors solely comes from the Government sources without any social funding. The law has not provided for a channel for mobilizing financial and other contributions from the society. The spread of positive values of organ donation to the society, therefore, is also restricted, while the law needs to play a pioneering role in shaping organ donation as a new value of the modern society. Due to the absence of social funding, financial support policies for the living donors (to encourage them to donate organs, mainly kidneys, instead of selling them) have not been formulated.

The voluntary organ donation system could be improved if more attention was paid to the importance of human relationships (Areen 1988). Human relationships involve the concern about and tribute to the donors and their families not only during the memorial service but also the time after that. Such feeling and action can be in the form of the exchange of information about the health and gratitude of the organ receivers, so that the donors and their families feel that their decision was right and their deceased loved ones are still somehow alive and helpful. Vietnam has not considered yet the need to provide the donors and relatives of deceased donors with social work services when they are in need and with therapy, functional rehabilitation, to promote the ability to solve problems of themselves and families (which is confronting the fact that their loved ones have died, confronting torment and regret when donating organs of a loved one, misunderstandings and social prejudices), and to help the donors connect with social resources, services, and opportunities.

THE POLICY ON COMBATING ORGAN TRADING ARISING FROM POOR ORGAN DONATION IN VIETNAM: STATORY LAW AND SHORTCOMINGS

\section{The Law of Vietnam on Prevention and Handling of Crimes Relating to Organ Trading}

Due to a limited supply of organs from the braindead, people inevitably resort to organs, mainly kidneys, supplied by living people. Except for several cases where the living donors are family members who 
voluntarily donate organs due to their blood relationship, other people supply living organs through sale and purchase relation. This issue arises due to the supply-demand principle. As mentioned by Steiner (2017:53), "when there are so many rich patients waiting for a kidney, when there are so many poor people desperate for cash, then there is organ trafficking". In other words, the gap between the fact that the rich are ready to afford a kidney and the fact that the poor are ready to sell their own kidney is so large that trafficking can easily intervene and offer an illegal transaction to both, along with hefty profits to the brokers and the surgeons (Steiner 2017:53). Therefore, it is inevitable for illegal organ trading, even organ trafficking and appropriation, to occur because the supply of organs is too small to meet the demand for organ transplants. In Vietnam, according to the data of the Department of Crime Statistics and Information Technology under the management of the Supreme People's Procuracy (2021), the situation of dealing with human tissue or body part trading and appropriation within 3 years from the date such acts were first criminalized in the Penal Code 2015 (effective from $1 / 1 / 2018$ ) is as follows: the total number of cases tried by the Court was 9 with 13 defendants ( 5 cases with 8 defendants were tried in 2019 and 4 cases with 5 defendants were tried in 2020), and this figure may be higher because cases which have not been detected or prosecuted were not included.

In the recent years, Vietnam has promoted lawmaking and law enforcement activities in order to combat crimes relating to organ trading and trafficking. Vietnam's criminal policy is to criminalize the act of buying and selling (trading), trafficking, and appropriating human tissues or organs, and not to legalize the trading of organ. The law of Vietnam has set out provisions in the Law concerning Prevention of Human Trafficking 2011 and the Penal Code 2015, creating a legal corridor for the prevention and handling of related crimes. The Law concerning Prevention of Human Trafficking 2011 provides for activities to be carried out to detect and prevent the trafficking of human for sexual exploitation, forced labor, body organs or for other inhumane purposes as well as necessary measures to protect victims, those who reported crimes, witnesses, and their relatives. The Penal Code 2015 criminalizes acts involving the trading, trafficking and appropriation of human tissues or body parts (Article 154) ${ }^{1}$, human trafficking (Article

${ }^{1}$ Article 154 is cited and further analyzed in the section "Weaknesses of the law in combating crimes relating to organ trading".
150 ), and trafficking of a person under 16 (Article 151). Taking the victim's body parts is considered the circumstance that aggravates the penal liability mentioned in the bracket of heavier sanction applied to Murder (Article 123, clause 1, point $\mathrm{h}$ ), human trafficking (Article 150, clause 3, point b), and trafficking of a person under 16 (Article 151, clause 3, point d).

Therefore, the source of organs supplied by organ trading and appropriation is considered illegal in Vietnam. This is consistent with policies on organ donation and transplantation for non-commercial purposes and prohibits the trade of human organs and tissues set out in the Law on donation, removal and transplantation of human tissues and organs and the donation and recovery of cadavers 2006 (Article 4). Vietnam has been in favor of the solution which is to respect and protect the voluntariness in organ donation. The adherence to the principle of voluntariness in organ donation requires the issuance of regulations on prevention and sanction applied to cases where organs are transplanted involuntarily or for commercial purposes.

With the current legal infrastructure relying only on voluntariness, and mainly on the limited source of organs donated by the brain dead, the 'black' market of organs has formed and developed due to insufficient supply. This market will inevitably look for organs traded, trafficked, and appropriated. Nonetheless, the ban on organ appropriation and trading and the criminalization thereof are absolutely necessary. Human organs in particular and the body parts of human in general are always associated with human life, health, dignity, and human rights, thus not being considered as goods for trading on the market for commercial purposes. They are only given away for a noble and charitable purpose to save the life of another or many others. This is also consistent with the values and norms of beliefs, religions, and traditional culture as analyzed in the first part of this paper. To ensure social order and stability, values and standards of beliefs, religions, and traditional culture that form the solid foundation for social order and social stability, Vietnam does not advocate the right of individuals to decide to sell their organs, nor does it legalize the right to sell sex (prostitution), the right to pregnancy for other person in exchange of money (being pregnant for commercial purpose), and the right to die (euthanasia) due to a consistent paternalistic approach of the government. Besides, if organs are legally traded, in theory, the problem of scarcity of organs can be solved, but if they really are, this will do more harm than good. 
This is because to get a large sum of money from the sale of organs, the sellers may give up treatment, the chance to live, or even the opportunity to work for a living, and the organ can be subject to mortgage or pledge. The sellers themselves may be under pressure from creditors, or patriarchs in the family to earn money, etc. In general, practical observations have concluded that in countries where organ donation for profit is allowed, although this policy may play an important role, its negative effects will far outweigh the positive ones (Bernat, 1995).

\section{Weaknesses of the Law in Combating Crimes Relating to Organ Trading}

Although major legal instruments for the prevention of crimes relating to organ trading have been established, the law of Vietnam still has several shortcomings.

First, Vietnam has no appropriate regulation to effectively deal with violations of organ transplant establishments. There are currently 20 medical establishments licensed to conduct organ transplant where the professional qualification of surgeons and medical equipment are at a high level. For ordinary goods, the sale and purchase are implemented directly, but for human tissues and body parts alone, the transaction between the sellers and buyers cannot be carried out without medical institutions. The prevention of organ trading should have focused on such medical institutions but in fact they are overlooked. Many medical establishments have not set up a council to determine brain death, nor are they licensed to carry out organ transplant. They also conducted organ transplant for patients not on the national transplant wait list; did not establish a coordinating department for human organ transplantation; did not receive registration for organ donation in accordance with the prescribed process; did not report transplants and transplant results to the National Coordinating Centre for Human Organ Transplantation. The number of medical facilities that respect the rule of no financial exchange between donors and recipients is very small (Tran et al. 2021) $)^{2}$. Such violations created favorable conditions for the sale and purchase of organs and it is

\footnotetext{
${ }^{2}$ Synthesized from Tran Ngoc Sinh, General Secretary of Vietnam Society Of Organ Transplantation, some other medical officers (at the expert workshop "Tang Nguon Hien Mo, Bo Phan Co The Nguoi" (Increasing the Source of Human Tissues and Body Parts) held by the Ministry of Health dated $22 / 03 / 2021$ in Hochiminh City, Vietnam), lawyer Hoang Minh Hien, and his partners of HHM Vietnam Law-Office (who have been representing the defendants of criminal cases relating to organ trading offenses in Vietnam recently).
}

likely that organs supplied by such transactions will be used for transplantation in such medical facilities.

Under the Government's Decree No. 117/NDCP/2020 dated 28 September 2020 on administrative sanctions in the field of health, Vietnam has imposed only administrative punishment on such legal persons at a mild level, including a fine of between VND $60,000,000$ and VND 80,000,000 (equal to nearly 2,608 USD and 3,478 USD (exchange rate in 2020: 1USD = around $23,000 \mathrm{VND}$ ) for acts of taking, transplanting, using, storing tissues and human body parts for commercial purposes; conducting the removal and transplant of human tissues and body parts without recognition by a competent state authority as a qualified institution for doing so, and some other optional additional sanctions (Article 44, clauses 6 and 8).

Vietnam has not stipulated the case where the criminal is a legal person to have the grounds for inflicting punishment on medical institutions (being legal persons) that are engaged in the trading or transplantation of human tissues and parts of human body and corpse, even though they know that those tissues and parts are taken from transplantation activities. According to the Penal Code 2015, legal persons are those who only commit economic and environmental crimes, thereby not bearing penal liability for other crimes. As a result, there is no legal ground to handle such legal persons as the helpers in particular or to deal with crimes relating to organ trafficking and appropriation committed by legal persons in general.

Second, Vietnam is treating people who purchase organ for their own transplant as criminals, and even the sellers who sell their own organ are treated as criminals due to unclear provision. Under Article 154 of the Penal Code $2015^{3}$, they become the criminals

\footnotetext{
${ }^{3}$ Article 154 of Vietnam's Penal Code 2015 pertaining to "The trading, appropriation of human tissues or body parts" is as follows:

"1. Any person who purchase, sell, or appropriates human tissues or other body parts shall face a penalty of 03 to 07 -year imprisonment.

2. This offence committed in any of the following circumstances carries a penalty of $07-15$ years' imprisonment:

a) The offence is committed by an organized group; b) The offence is committed for commercial purposes; c) The offence involves abuse of the offender's position or power d) The offence is committed against $02-05$ people; đ) The offence has been committed more than once e) The offence causes $31 \%$ - $60 \%$ Whole Person Impairment (WPI) for the victim.

3 . This offence committed in any of the following circumstances carries a penalty of 12 - 20 years' imprisonment or life imprisonment: a) The offence is committed in a professional manner; b) The offence causes $\geq 61 \%$ WPI for the victim; c) The offence is committed against 06 or more people; d) The offence results in the death of the victim; đ) Dangerous recidivism.

4. The offender may also be liable to a fine of from VND $10,000,000$ to VND $100,000,000$, be prohibited from holding certain positions or doing certain works for 01 - 05 years".
} 
because of their organ trade. The act of buying and selling organs of the aforesaid buyers and sellers is criminalized in the same provision where the act of a broker is criminalized. However, while the act of brokers is very dangerous, because they connect organ sellers and organ buyers who are in difficult circumstances to take a certain amount of money as profit from the buyers' payment to donors, such act is only subject to punishment as applied to the act of an accomplice to the buyer and seller. Brokers fail to provide the right and necessary information, try to close the deal as soon as possible or cooperate with medical institutions with a poor technique for test and surgery, which increases the risks to the sellers' health. They may use violence against the sellers in various ways such as duress, biased information, straightforward lies, and deductions made from the payment promised (Steiner 2017). The proactive engagement of the brokers with the aforesaid nasty tricks and servere impact turns the organ trading which purely consists of "the buyer and the seller" (2 parties) or "the buyer - the broker - the seller" (3 parties) into a much more complicated and dangerous transactions (organ trafficking). However, the Penal Code 2015 does not distinguish the difference between the two terms "organ trading" and "organ trafficking" when the law-makers want to prosecute both the persons who sell their own organs and the persons buying organ for their own transplant, the brokers now becoming traffickers, and persons committing organ appropriation with the reference to the same provision of law.

\section{CONCLUSION AND RECCOMENDATIONS}

In Vietnam, organ donation is an emerging issue in the recent years; therefore, it has not been mentioned in the beliefs, religions and traditional culture of Vietnamese people. However, organ donation faces both barriers and contributing factors determined from an analysis of the Vietnamese context with conceptions embraced in traditional culture, religions and beliefs which are correlative and entwined, affecting people's mind and willingness to donate organs. In order to promote voluntary organ donation, the law needs to recognize the aforementioned barriers and driving force, while simultaneously gradually changing the conceptions of indigenous beliefs and traditional culture. The law of Vietnam needs to continue considering organ donation the highest level of humanity and honor organ donation as a self-sacrifice for others. Once organ donation has been determined as the highest level of humanity, the law should create favorable conditions for granting support to organ donors, provide long-term and substantial care to the relatives of organ donors after their death and reduce involuntary or commercial organ transplantations.

First, it is necessary to set out regulations on honoring organ donors and their families in an appropriate manner, rather than giving only the donors a "medal" as prescribed in Article 17 of the Law on Donation, Removal and Transplantation of Human Tissues and Organs and Donation and Recovery of Cadavers in 2006. In particular, the law should extend the scope of people to be honored including the families of donors in case they agree to donate the organs of a brain-dead relative who has not registered for donation before brain death.

Second, there should be a legal corridor to promote the socialization of resources to support organ donation and to expand the role of organizations and individuals in providing support, especially financial ones, to organ donors. Legislation should provide for ensuring public and adequate financial support for organ sellers to become organ donors, thereby preventing them from going to the black market for bigger proceeds. Also, they should be given medical and insurance support in order to reduce the risks arising from the donation of organs and post-donation period. To this end, a legal framework should be established to determine the support criteria, support procedures and mobilization of support (by establishing associations, funds to support organ donors in addition to government's resource).

Third, there should be regulations on stricter punishment imposed on medical establishments that conduct transplants of organs from illegal sources with an increase in fines compared to Government's Decree No. 117/ND-CP/2020 dated 28 September 2020 on administrative sanctions in the field of health. In particular, such medical facilities should be subject to criminal liability if they assist in organ trading transactions, and the criminal law should expand the scope of criminal liability of legal persons, instead of maintaining current regulations (Article 76 of the Penal Code 2015) which require commercial legal persons to be criminally responsible for economic crimes and environmental crimes.

Fourth, it is necessary to have more specific and separate regulations on criminalization of brokers' offense instead of the same legal framework applied to those buying organs for their own transplant and sellers 
of their own organs. In addition, the criminal law needs to differentiate organ trading from organ trafficking, and to be directed towards punishing brokers and their supporters, rather than people who buy organs for transplantation for themselves and who sell their own organs.

Having established the principle of voluntariness in organ donation with righteousness and altruism, the law should strictly defend this principle, in order to promote voluntary organ donation and minimize "halfheartedness", according to which this principle is established but not upheld by a sufficient number of legal regulations, resulting in laxity in the law and indirectly facilitating the trading and appropriation of organs. Consequently, this raises requirements for the improvement of the criminal law to strictly handle and exert strong deterrent effect on acts involving the trading and trafficking of organs.

\section{REFERENCE}

Areen, Judith. 1998. "A Scarcity of Organs." Journal of Legal Education 38(4):555-565

Bernat, Erwin. 1995. "Marketing of Human Organs." Medicine and law 181-190.

Bruzzone, P. 2008. "Religious Aspects of Organ Transplantation." Transplantation Proceedings. Elsevier. https://doi.org/10.1097/01.tp.0000331398.11265.f4

Cadiere, Leopold. 1997. Ve Van Hoa Va Tin Nguong Truyen Thong Nguoi Viet [Vietnamese Culture and Traditional Belief]. Translated by Do Trinh Hue. Hanoi: Van Hoa Thong Tin.

Chan-On, C., \& Sarwal, M. M. 2017. "A comprehensive analysis of the current status and unmet needs in kidney transplantation in Southeast Asia." Frontiers in medicine, 4, 84. https://doi.org/10.3389/fmed.2017.00084

Chen, Chao-Long, Catherine S. Kabiling, and Allan M. Concejero. 2013. "Why Does Living Donor Liver Transplantation Flourish in Asia?" Nature Reviews Gastroenterology \& Hepatology 10(12):746-751.

https://doi.org/10.1038/nrgastro.2013.194

Circular no. 104/2017/TT- BTC of 2017 (Vietnam)

Concejero, Allan $\mathrm{M}$ and Chao-Long Chen. 2009. "Ethical Perspectives on Living Donor Organ Transplantation in Asia." Liver Transplantation 15(12):1658-1661. https://doi.org/10.1002/lt.21930

Decree No. 117/2020/ND-CP of 2020 (Vietnam)

Department of Crime Statistics and Information Technology under the management of the Supreme People's Procuracy. "Extract of Data on Handling the Trading, Appropriation of Human Tissues or Body Parts (Article 154 of the Penal Code 2015).

Duong Hai. 2018. "Xoa Bo Quan Niem "Chet Toan Thay", Hang Tram Tang Ni, Phat Tu No Nuc Dang Ky Hien Tang." [Removing the Belief of "Death with the Body Integrity", hundreds of Buddhism Followers Eagerly Enroll Organ Donation]. Suc Khoe \& Doi Song, October 2. https://suckhoedoisong.vn/xoabo-quan-niem-chet-toan-thay-hang-tram-tang-ni-phat-tu-nonuc-dang-ky-hien-tang-n149065.html (accessed February 3, 2021).

Hai Van. 2018. "Can Thay Doi Suy Nghi Ve Hien Tang." [The Need to Change the Mindset on Organ Donation]. Nhan Dan,
December 6. https://nhandan.com.vn/baothoinay-xahoi/canthay-doi-suy-nghi-ve-hien-tang-343103/ (accessed February 4, 2021).

Huang, Jie-Fu, Hai-Bo Wang, Shu-Sen Zheng, Yong-Feng Liu, BingYi Shi, Zhong-Yang Shen, Sheng-Shou Hu, Qi-Fa Ye, WuJun Xue, Xiao-Shun He, and Feng Huo. 2015. "Advances in China's Organ Transplantation Achieved with the Guidance of Law." Chinese Medical Journal 128(2):143-146. https://doi.org/10.4103/0366-6999.149183

Lan Anh. 2021. "Kho Xu Vu Ben Cho Tim Muon Gap Nguoi Nhan Tim." [Heart Donor Wants to Meet Receiver: A Dilemma]. Tuoi Tre, March 22. https://tuoitre.vn/kho-xu-vu-ben-cho-timmuon-gap-nguoi-nhan-tim-2021032208050869.htm (accessed March 25, 2021).

Law concerning Prevention of Human Trafficking of 2011 (Vietnam)

Law on donation, removal and transplantation of human tissues and organs and the donation and recovery of cadavers of 2006 (Vietnam)

National ASEAN 2020 Committee. "Religion and Beliefs." https://www.asean2020.vn/web/asean_en/tin-nguong-tongiao (accessed February 4, 2021).

Nguyen, Duc Lu. 2007. Nhung Dac Diem Co Ban Cua Mot So Ton Giao Lon O Viet Nam [Main Features of Some Major Religions in Vietnam]. Hanoi: Ton Giao.

Nguyen, Q.H. 2020. "Moi Quan He Giua Tin Nguong, Ton Giao Va Ca Nhan." [The Relationship among Belief, Religion, and Individual] p. 76 in Phap luat ve tu do tin nguong, ton giao [Law on the freedom of belief and religion], edited by Nguyen. T. Q. A., Vu. C. G., and La. K. T. Hanoi: HongDuc.

Nguyen, Thanh Tuan. 2012. Van Hoa Ban Dia Viet Nam, Khuynh Huong Phat Trien Hien Dai [Native Vietnamese Culture, the Tendency of Modern Evolution]. Hanoi: Van Hoa Thong Tin \& Vien Van Hoa.

Nhu Tho. 2012. "Lam Ban Ve Tinh Duy Tinh Cua Nguoi Viet: Rang Hay Thi That La Hay?" [Discussion on Vietnamese Sentimentalism: Is It Good?]. PetroTimes, July 28. https://petrotimes.vn/lam-ban-ve-tinh-duy-tinh-cua-nguoi-vietrang-hay-thi-that-la-hay-16585.html (accessed February 3, 2021)

Ozdag, N. 2004. "Public Awareness and Acceptance of Tissue and Organ Donation." EDTNA-ERCA Journal 30(4):188-195. https://doi.org/10.1111/j.1755-6686.2004.tb00366.x

Penal Code of 2015 (Vietnam)

Pham, Con Son. 2011. Gia Le Xua Va Nay [Family Rites - Past and Present]. Hanoi: Thanh Nien.

Pham, Nguyen Tuong. 2015. "Chet Nhe Nhu Mot Su Cho Di." [Death as A Giving]. Tuoi Tre, January 1, 2015. https://tuoitre.vn/chet-nhe-nhu-mot-su-cho-di-698685.htm (accessed February 3, 2021).

Röcklinsberg, Helena. 2009. "The Complex Use of Religion in Decisions on Organ Transplantation." Journal of Religion and Health 48(1):62-78. https://doi.org/10.1007/s10943-008-9209-7

Steiner, Philippe. 2017. "Secrecy and Frontiers in Illegal Organ Transplantation." In the Architecture of Illegal Markets. Oxford: Oxford University Press. https://doi.org/10.1093/oso/9780198794974.003.0003

Tai, Michael Cheng-Tek. 2009. "An Asian Perspective on Organ Transplantation." Tzu Chi Medical Journal 21(1):90-93. https://doi.org/10.1016/S1016-3190(09)60017-3

Toan Anh. 1992. Nep Cu, Con Nguoi Viet Nam [Traditional Customs, Vietnamese People]. Ho Chi Minh: Thanh pho Ho Chi Minh.

Tran, Ngoc Sinh. 2021. "Tang Nguon Hien Mo, Bo Phan Co The Nguoi" (Increasing the Source of Human Tissues and Body Parts)." Expert Workshop Proceedings. Hochiminh.

Tran, Ngoc Them. 2016. He gia tri Viet Nam tu truyen thong den hien dai va con duong toi tuong lai [The Vietnamse Values 
System: from the Past to Present, and the Path to Future]. Vanhoavannghe: Ha Noi.

Tran, Trong Kim. 2002. Viet Nam Su Luoc [Overview of Vietnamese History]. Danang: Da Nang.
Vietnam National Coordinating Centre for Human Organ Transplantation. http: Vnhot.vn (accessed 28 June 2021).

Received on 11-05-2021

Accepted on 02-07-2021

Published on 09-07-2021

https://doi.org/10.6000/1929-4409.2021.10.141

(C) 2021 Le Lan Chi; Licensee Lifescience Global.

This is an open access article licensed under the terms of the Creative Commons Attribution Non-Commercial License (http://creativecommons.org/licenses/by-nc/3.0/) which permits unrestricted, non-commercial use, distribution and reproduction in any medium, provided the work is properly cited. 